\title{
Isolation and identification of bacteria with cellulose-degrading potential from soil and optimization of cellulase production
}

\author{
Shweta Ashok Bhagat, Seema Sambhaji Kokitkar* \\ Department of Biotechnology, Changu Kana Thakur College of Arts, Commerce and Science, New Panvel, Raigad, Maharashtra, India.
}

\begin{tabular}{l} 
ARTICLE INFO \\
\hline Article history: \\
Received on: May 27, 2021 \\
Accepted on: July 30, 2021 \\
Available online: November 10, 2021
\end{tabular}

Key words:

Screening,

carboxymethylcellulose, cellulase,

Bacillus, DNSA, optimization

\begin{abstract}
Soil is one of the most promising sources for the presence of a variety of microorganisms which produce different hydrolytic enzymes. Such microorganisms include bacteria, fungi, etc. The ability to produce hydrolytic enzymes makes them potential candidates for hydrolysis of complex polymeric substrates. The present study aims at screening, isolating, and characterizing cellulolytic bacteria isolated from soil samples. Nine different soil samples were collected from different locations near Raigad district, Maharashtra, India. Carboxymethylcellulose (CMC) was used as a sole source of carbon for screening of cellulase-producing isolates. Forty-five different cellulase-producing bacteria were isolated based on their ability to decolorize Congo red and iodine. The morphological and molecular characterization of seven best isolates was carried out for their identification. All seven isolates were identified to be Bacillus species using 16s rRNA gene-based sequencing. The optimization of cellulase enzyme production of these seven isolates was carried out by using different parameters such as $\mathrm{pH}$, temperature, and carbon sources. Majority of the cellulase producers identified in the present research work were found to be mesophiles. $\mathrm{pH}$ ranging from 6 to 8 was found to be most suitable to produce cellulase enzyme by the isolates. The data suggest that polymeric substances such as starch and $\mathrm{CMC}$ act as inducers for cellulase production.
\end{abstract}

\section{INTRODUCTION}

Cellulose is one of the most abundantly available wastes from agriculture and industrial origin. It is also obtained in large amounts from industries such as food, paper, and pulp [1]. Due to its availability in large amounts, it has become the most promising renewable energy resource [2]. Cellulose is made up of multiple $\mathrm{D}$-glucose units and is formed due to the condensation of these glucose units through $\beta(1 \rightarrow 4)$-glycosidic bonds [3]. There are several studies on the conversion of this lignocellulosic biomass into fermentable sugars. Methods such as acid, alkali, or heat treatments can be used for efficient conversion of cellulosic biomass. These methods have several disadvantages such as use of harsh chemicals, pollution, high cost, high energy consumption, etc. $[4,5]$. The most effective approach for the hydrolysis of lignocellulosic waste is thought to be the use of microbial

\footnotetext{
*Corresponding Author

Seema Sambhaji Kokitkar, Department of Biotechnology, Changu Kana Thakur College of Arts, Commerce and Science, New Panvel, Raigad, Maharashtra,India.E-mail: seemaskk11@gmail.com
}

enzymes [6]. The degradation of this biomass using microbial enzymes can help utilize this resource for the production of many economically important products such as biofuels, animal feeds, etc. [7]. The most commonly used enzymes for the hydrolysis of lignocellulosic biomass are cellulases [8]. Cellulase is a set of three enzymes which acts in a synergistic manner to hydrolyze the lignocellulosic biomass. It includes endoglucanases (EC 3.2.1.4), exoglucanases, also known as cellobiohydrolases (EC 3.2.1.91), and $\beta$-glucosidases (EC 3.2.1.21) [9]. The endo- $\beta$-1, 4-glucanases, and exo- $\beta-1,4$ cellobiohydrolases degrade cellulose to get smaller cello-oligosaccharides. The oligosaccharides obtained are then hydrolyzed to glucose by $\beta$-glucosidase [10].

Soil, being the richest ecosystem, is the most important source for the presence of hydrolytic enzyme-producing microbes such as bacteria, fungi, actinomycetes, etc. The microorganisms in the soil produce different hydrolytic enzymes such as amylases, proteases, cellulases, lipases, etc. There are several reports available on the production of cellulases from fungi. Aspergillus and Trichoderma species are the most used fungi for the production of cellulases at commercial scale [11]. Cellulase was also reported to be produced 
from a fungus named Penicillium funiculosum. The cellulase enzyme was produced under submerged fermentation using rice husk powder as a carbon source [12]. However, the production of bacterial cellulases at the commercial scale was limited due to its complexity as well as difficulty in the extraction and purification. A wide range of researches has been initiated upon the application of bacterial cellulases [13]. Cellulases from the bacterial sources such as Pseudomonas and Sphingomonas are commercially used in the textile industry. Cellulase produced from Bacillus species has been extensively studied for its use in laundry detergents [14]. Bacteria can be chosen over fungi for the production of cellulases at the industrial scale due to their high growth rate [15]. Moreover, genetic manipulations of bacteria are easier when compared to fungi [16]. The present study was focused on the screening and isolation of the potential cellulase-producing bacteria and the optimization of different parameters to maximize cellulase production. The bacterial isolate with the promising cellulolytic potential could be further explored for the production and purification of cellulase enzyme. The purified enzyme can be utilized in industrial applications as well as for the degradation of lignocellulosic biomass.

\section{MATERIALS AND METHODS}

\subsection{Chemicals}

All the chemicals were of analytical grade and purchased from Sisco Research Laboratories Pvt. Ltd. India. Media components and Congo red (microbiology grade) were purchased from HiMedia Private Ltd. India.

\subsection{Sample Collection}

Nine different soil samples were selected for isolation of cellulaseproducing bacteria from different regions of Raigad district. The preferred areas for collection of soil samples were dump yards, undisturbed garden soil, and undisturbed forest soil. The soil samples were collected in sterile polythene bags.

\subsection{Screening and Isolation of Cellulase-Producing Bacteria}

Serial dilutions of the soil samples were prepared using $0.85 \%$ saline and the higher dilutions were plated on the screening medium composed of carboxymethylcellulose (CMC) $(0.5 \%)$, $\mathrm{NaNO}_{3}(0.1 \%), \mathrm{K}_{2} \mathrm{HPO}_{4}(0.1 \%), \mathrm{KCl}(0.1 \%), \mathrm{MgSO}_{4}(0.05 \%)$, yeast extract $(0.05 \%)$, and agar agar $(2.0 \%)[17,18]$. Plates were incubated at $37^{\circ} \mathrm{C}$ for 48 hours. Isolated organisms were maintained on fresh agar slants using the same media composition at $4^{\circ} \mathrm{C}$. For screening of the cellulase-producing organisms, point inoculation of the isolates was carried out on the same cellulase screening media plates, followed by incubation at $37^{\circ} \mathrm{C}$ for 48 hours. The plates were flooded with $0.1 \%$ Congo red and further washed using $1 \mathrm{M}$ sodium chloride to visualize the zone of clearance. Gram's iodine was also used for screening of cellulaseproducing isolates [18].

\subsection{Identification of Bacteria}

The isolated bacteria were characterized by performing Gram's staining to identify their morphology. Genotypic characterization of bacterial isolates was carried out at the National Collection of Industrial Microorganisms (NCIM), Council of Scientific \& Industrial Research- National Chemical Laboratory (CSIRNCL), Pune, India. The molecular identification of the cellulaseproducing bacterial isolates was carried out using 16s rRNA gene sequencing. This was carried out in two steps.

\subsubsection{DNA isolation and $P C R$}

Isolated bacteria were subjected to DNA extraction using HiPurA $^{\mathrm{TM}}$ bacterial genomic DNA purification kits [19]. Agarose gel electrophoresis was carried out in order to check the integrity of the extracted DNA and the quantification was conducted using NanoDrop Lite Spectrophotometer (Thermo Scientific). Exactly $50 \mathrm{ng}$ of the above-extracted DNA was taken for 16S rRNA gene amplification. The following universal bacterial forward and reverse primers were used: 16F27-(5'AGAGTTTGATCMTGGCTCAG3') and 16R1492(5'TACGGYTACCTTGTTACGACTT3'). The polymerase chain reaction (PCR) was carried out in $50 \mu$ reaction mixture containing $3.5 \mathrm{pM}$ primers (Eurofins), $5 \mathrm{mM}$ deoxynucleotide triphosphate (dNTPS-Genei), 1U Taq polymerase (Genei), PCR reaction buffer (with $15 \mathrm{mM} \mathrm{MgCl}_{2}$ ), DNA template, and PCR water. PCR conditions were 34 cycles of 30 seconds at $95^{\circ} \mathrm{C}$, 30 seconds at $55^{\circ} \mathrm{C}$, and 1 minute 30 seconds at $72^{\circ} \mathrm{C}$ and final extension at $72^{\circ} \mathrm{C}$ for 7 minutes.

\subsubsection{DNA sequencing}

After the purification of the PCR product partial 16S rRNA gene sequencing was carried out using the $\mathrm{ABI} 3,500 \times 1$ genetic analyzer (Invitrogen/Life Technologies) [20]. The sequenced data were further analyzed by Basic Local Alignment Search Tool (BLAST) with closest culture sequence retrieved from the National Centre for Biotechnology Information (NCBI) database [21].

\subsection{Production of Cellulase Enzyme}

Production of cellulase was carried out for seven efficient cellulase-producing isolates. The organisms were inoculated in a liquid medium containing $1 \% \mathrm{CMC}, 0.1 \% \mathrm{NaNO}_{3}, 0.1 \% \mathrm{~K}_{2} \mathrm{HPO}_{4}$, $0.1 \% \mathrm{KCl}, 0.05 \% \mathrm{MgSO}_{4}$, and $0.05 \%$ yeast extract $(\mathrm{pH} 7.0)$ and incubated at $37^{\circ} \mathrm{C}$ for 24 hours. The growing cultures were further transferred into the production medium with the same composition and incubated for 72 hours at constant stirring at $130 \mathrm{rpm}$ at $37^{\circ} \mathrm{C}$ using incubator shaker (Orbitek ${ }^{\mathrm{R}}$ LEBT, Scigenics Biotech Pvt Ltd, Chennai, India). The production medium was centrifuged at $10,000 \mathrm{rpm}$ for 10 minutes to get the cell-free supernatant. This cell-free supernatant was used as a crude enzyme extract for cellulase assay.

\subsection{Cellulase Assay}

The cellulase activity was carried out using the method described by Maravi and Kumar [17]. The assay was carried out by preparing a reaction mixture containing $0.1 \mathrm{ml}$ of crude enzyme extract with 1 $\mathrm{ml}$ of $0.5 \%$ CMC prepared in $50 \mathrm{mM}$ phosphate buffer ( $\mathrm{pH} 7) .0 .9$ $\mathrm{ml}$ of $50 \mathrm{mM}$ phosphate buffer $\mathrm{pH} 7.0$ was added to the tube in order to make up a volume $2.0 \mathrm{ml}$. The mixture was further incubated at $50^{\circ} \mathrm{C}$ for 30 minutes in a water bath. $3.0 \mathrm{ml}$ of dinitrosalicylic acid 
(DNSA) reagent was added to reaction tube to stop the reaction. To the control tube, crude enzyme was added after the stop solution, i.e., DNSA. After boiling for 5 minutes, the released sugar units were estimated according to protocol of Miller [22] with certain modifications. The enzyme activity was calculated in terms of the micromoles of glucose units released in 1 minute using the standard graph of glucose.

\subsection{Optimization of Cellulase Activity}

The optimization of culture conditions was carried out for maximum enzyme production. The parameters analyzed for the optimization were $\mathrm{pH}$, temperature, and carbon source.

\subsection{1. $\mathrm{pH}$}

The effect of $\mathrm{pH}$ on the enzyme production was checked by growing the isolates in a production medium adjusted at different $\mathrm{pH}$, i.e., $2,4,6,7,8$, and 10 . The $\mathrm{pH}$ of the media were adjusted by using $1 \mathrm{~N} \mathrm{NaOH}$ and $1 \mathrm{~N} \mathrm{HCl}$.

\subsubsection{Temperature}

The effect of temperature on enzyme production was checked by growing the isolates in a production medium and incubating it at temperatures $4^{\circ} \mathrm{C}, 10^{\circ} \mathrm{C}, 28^{\circ} \mathrm{C}, 37^{\circ} \mathrm{C}$, and $50^{\circ} \mathrm{C}$.

\subsubsection{Carbon source}

The effect of carbon source on the enzyme production was checked by preparing the production medium by replacement of the carbon source $\mathrm{CMC}$, i.e., CMC with glucose, sucrose, starch, and maltose. The isolates were grown at these different production media and incubated at $37^{\circ} \mathrm{C}$ for 72 hours. The cellfree supernatant in each of the above case was used as crude enzyme sources to check enzyme activity.

\subsection{Statistical Analysis}

All the experiments in the present study were carried out in triplicates and the data were obtained in the form of mean \pm standard error. The data were subjected to two factor analysis of variance (ANOVA) test with significance levels of $p<0.05$ using Microsoft excel 2013.

\section{RESULTS AND DISCUSSION}

\subsection{Screening}

Forty-five different bacterial cultures were isolated from nine soil samples. The isolates were numbered from S1-1 to S7-6 based on their origin of soil and number of isolates obtained per soil sample. The cellulolytic potential of the isolates was confirmed by flooding the plates using $0.1 \%$ Congo red. Gram's iodine was also used for screening of cellulolytic bacterial colonies. Bacterial isolates showed different zones of clearance around the colonies. The zone of clearance around the colony is an indicator of cellulolytic potential of the isolates [23]. Isolate S1-4 did not show the zone of clearance with $0.1 \%$ Congo red. However, it was significantly visible with Gram's iodine.

\subsection{Identification of Bacteria}

The isolates showing greatest cellulolytic potential on screening plates were further selected for morphological characterization and molecular identification. All the seven isolates were found to be Gram-positive in nature. The morphology of all the isolates was found to be rod-shaped.

All the seven bacterial isolates were identified by $16 \mathrm{~S}$ rRNA genebased sequencing which was carried out at NCIM, CSIR-NCL, Pune. The molecular characterization revealed that all the isolates belonged to genus Bacillus. NCBI BLAST analysis suggested that although all the isolates were identified to be Bacillus, their species were different namely Bacillus subtilis, Bacillus flexus, Bacillus licheniformis, and Bacillus paralicheniformis. Table 1 presents the details of identification of all the isolates with their accession numbers received for the genes from NCBI Genbank. The data suggest that the Bacillus species has the great potential to produce cellulolytic enzymes. Maravi and Kumar [17] isolated and identified two potential cellulolytic strains, one of which was found to be B. licheniformis. Sadhu et al. [24] isolated Bacillus strain from a cow dung sample. The isolated strain had a potential to produce thermotolerant endoglucanase enzyme (CMCase). Shanmugapriya et al. [8] also reported similar findings with purification of cellulase enzyme from Bacillus species. The isolation of the bacteria was carried out from the cow dung sample. Saha et al. [25] isolated eight potential cellulolytic bacteria

Table 1. Molecular identification of the isolates.

\begin{tabular}{|c|c|c|c|c|}
\hline S. No & Isolate & $\begin{array}{l}\text { Accession number received from } \\
\text { NCBI Genbank }\end{array}$ & Organism found with identity & $\begin{array}{l}\text { Percentage } \\
\text { identity }\end{array}$ \\
\hline 1. & S1-1 & MZ342583 & B. subtilis with accession number CP053102.1 & $100 \%$ \\
\hline 2. & S1-4 & MZ342581 & B. flexus with accession number NR_113800.1 & $100 \%$ \\
\hline 3. & S3-3 & MZ342584 & B. subtilis with accession number CP053102.1 & $100 \%$ \\
\hline 4. & S4-1 & MZ342585 & $\begin{array}{l}\text { B. licheniformis with accession number } \\
\text { CP034569.1 }\end{array}$ & $99.86 \%$ \\
\hline 5. & S4-2 & MZ342586 & $\begin{array}{l}\text { B. licheniformis with accession number } \\
\text { CP034569.1 }\end{array}$ & $100 \%$ \\
\hline 6. & S7-2 & MZ342582 & $\begin{array}{l}\text { B. paralicheniformis with accession number } \\
\text { KY694465.1 }\end{array}$ & $99 \%$ \\
\hline 7. & S7-6 & MZ342587 & $\begin{array}{l}\text { B. licheniformis with accession number } \\
\text { CP034569.1 }\end{array}$ & $100 \%$ \\
\hline
\end{tabular}




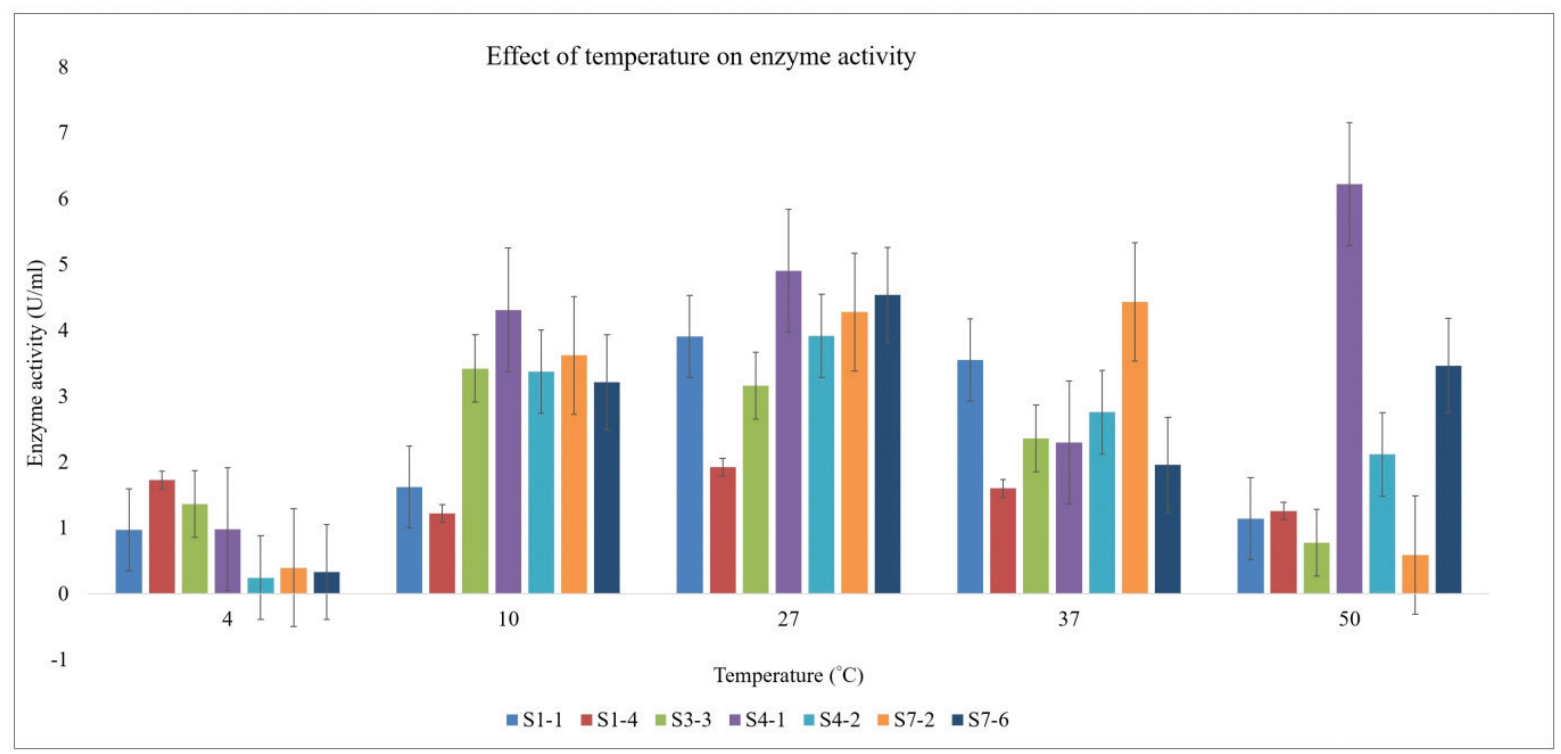

Figure 1. Effect of temperature on cellulase activity of different isolates.

from soil samples. Three out of these eight bacterial species were identified to be Bacillus sp., Bacillus cereus, and Bacillus megaterium. Along with Bacillus species, other bacterial genera also have the capability to produce cellulolytic enzymes. Lednická et al. [26] isolated and identified different cellulolytic strains from Belgian and Czech soils. The enrichment of these samples was carried out on flax or sisal fibers as sole sources of carbon. The bacteria isolated in the study were found to be strains of Cellulomonas, Flavobacterium, Cellvibrio, Achromobacter, and Pseudomonas. There are many reports available on the isolation of cellulolytic fungi. A fungus named Myceliophthora thermophila SH1 was explored for its cellulolytic and xylanolytic potential. The isolate was originally obtained from a source of hot spring and was able to show efficient cellulase and xylanase production under solid state fermentation [27]. Ja'afaru [28] isolated 110 different cellulase and xylanase producing fungi from saw dust, soil, and decaying wood samples. The isolate showing maximum cellulolytic potential was found to be Trichoderma species. The literature suggests that both bacteria and fungi have the ability to produce cellulase enzymes which can be further explored for their cellulolytic potential.

\subsection{Optimization of Cellulase Production}

The above-mentioned seven best isolates were optimized for their cellulolytic potential at different conditions. The effect of $\mathrm{pH}$, temperature, and different carbon sources was checked on these selected isolates with respect to their cellulase activity. The optimum temperature for the enzyme activity of six out of seven isolates was found to be $27^{\circ} \mathrm{C}$. The isolates named $\mathrm{S} 1-1, \mathrm{~S} 1-4, \mathrm{~S} 3-$ 3, S4-2, S7-2, and S7-6 were found to show maximum cellulase activity at $27^{\circ} \mathrm{C}$. The highest activity at this temperature was shown by isolate S7-6 and it was found to be $4.544 \mathrm{U} / \mathrm{ml}$ (Fig. 1). These results were found to be comparable to the findings of Premalatha et al. [4] wherein Enhydrobacter species were isolated from leaf litter compost sample for the production of cellulase enzyme and the activity was found to be highest at $30^{\circ} \mathrm{C}$. The isolates named S1-1, S1-4, and S7-2 showed almost comparable activities at $37^{\circ} \mathrm{C}$. The enzyme production of all above-mentioned isolates was found to be reduced at $50^{\circ} \mathrm{C}$. The data suggest that the cellulase enzyme can be produced at $27^{\circ} \mathrm{C}-37^{\circ} \mathrm{C}$ by these isolates. Similar results were reported by Islam et al. [29], in a known Bacillus strain where the highest cellulase production was observed at $35^{\circ} \mathrm{C}$ and the enzyme production was found to be reduced with an increase in the fermentation temperature above $40^{\circ} \mathrm{C}$. Rasul et al. [30] also reported that the enzyme activity increases gradually up to $40^{\circ} \mathrm{C}$ and is found to be decreased at higher temperatures. The isolate named S4-1 was found to show highest activity, i.e., 6.226 $\mathrm{U} / \mathrm{ml}$ at $50^{\circ} \mathrm{C}$, which suggests that this Bacillus strain may be is a type of thermotolerant bacterium. The results were comparable to Sadhu et al. [24]. The Bacillus strain isolated in this study was found to have maximum cellulase activity at $50^{\circ} \mathrm{C}$. Gautam et al. [31] also reported the novel cellulolytic fungi from municipal solid wastes which were found to produce the cellulolytic enzyme at the temperature ranging from $40^{\circ} \mathrm{C}$ to $50^{\circ} \mathrm{C}$.

The effect of $\mathrm{pH}$ on cellulase production was checked and it was found that all the isolates needed a different $\mathrm{pH}$ for maximum enzyme production (Fig. 2). Isolates S1-1, S7-2, and S7-6 showed maximum enzyme production at $\mathrm{pH}$ 6. The highest enzyme activity was reported by isolate $\mathrm{S} 1-1$ at $\mathrm{pH} 6$ and it was found to be $3.082 \mathrm{U} / \mathrm{ml}$. $\mathrm{pH} 7$ was found to be optimum for enzyme production by isolate S1-4. Isolates S3-3 and S4-2 were found to show maximum enzyme activity at $\mathrm{pH}$ 8. The above-mentioned data suggest that slightly acidic to slightly alkaline $\mathrm{pH}$, i.e., $6-8$, was found to be the most suitable $\mathrm{pH}$ range for cellulase production. Shanmugapriya et al. [8] reported that slightly acidic to neutral $\mathrm{pH}$ supports maximum production of cellulase enzyme. The isolate named S4-1 showed the maximum enzyme production at $\mathrm{pH} 4$. However, the enzyme activity shown by this isolate was found to be poor when compared to the other isolates under the study. The data are comparable to the findings reported by Maryam et al. [32] on Bacillus cellulosilyticus which showed optimum cellulase production at $\mathrm{pH} 5$ using alkali pretreated substrate as a source of carbon. Nandimath et al. [33] isolated Bacillus and 


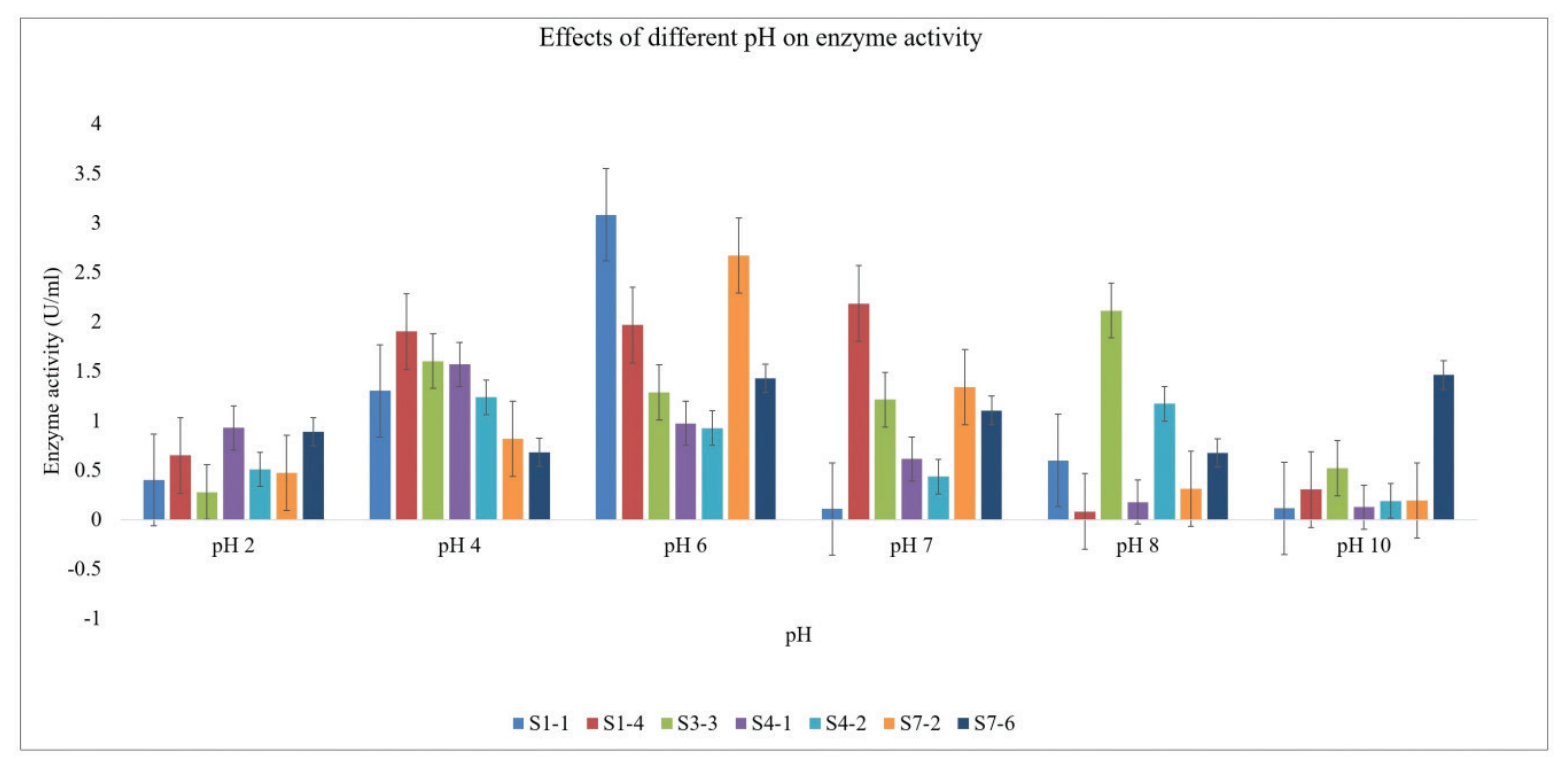

Figure 2. Effect of $\mathrm{pH}$ on cellulose activity of different isolates.

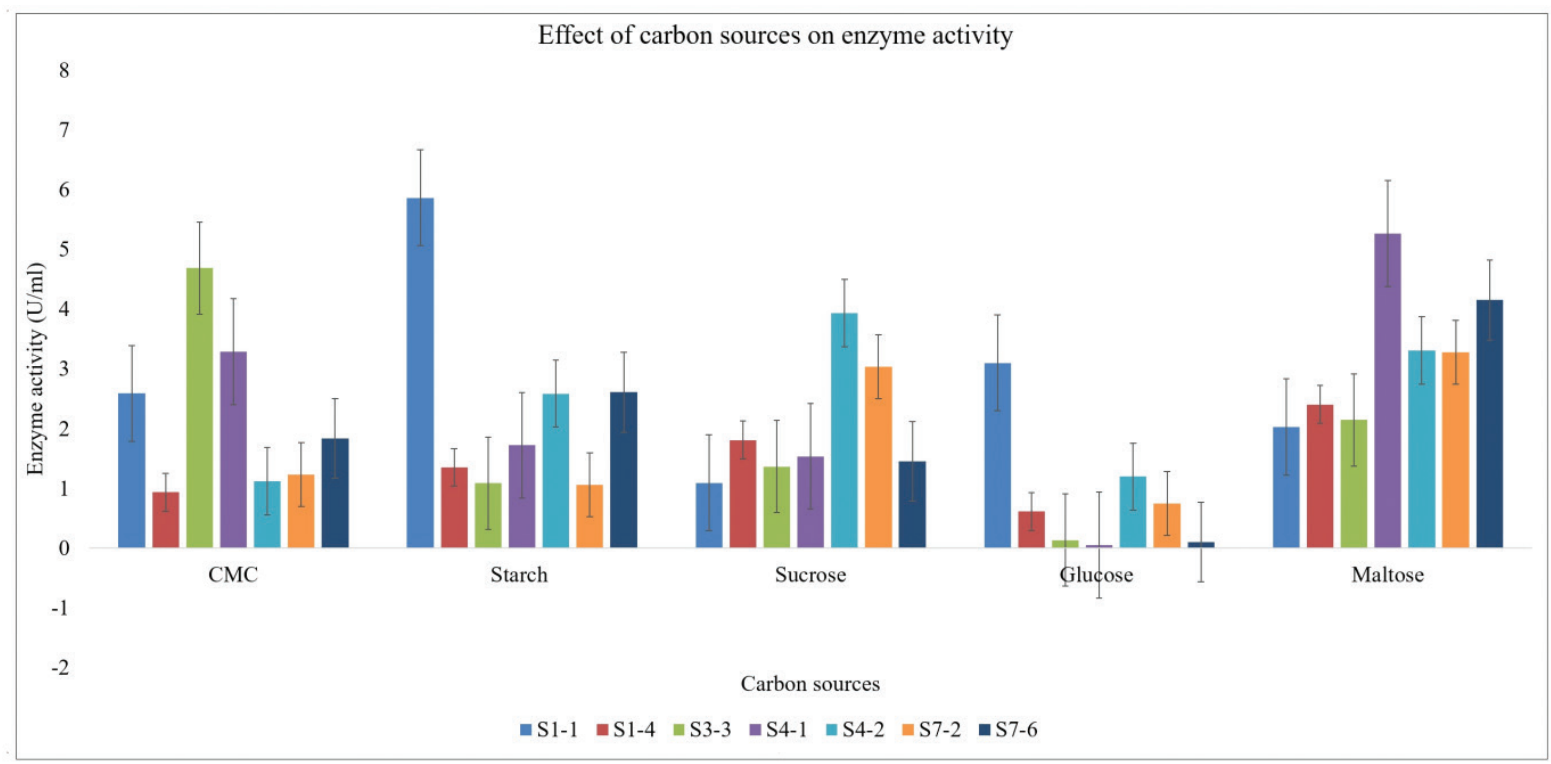

Figure 3. Effect of carbon sources on cellulase activity of different isolates.

Pseudomonas species having cellulolytic potential. The optimum $\mathrm{pH}$ for cellulase production by these two isolates was found to be 5. The data indicate that Bacillus species have the capability to produce cellulase enzyme in a wide $\mathrm{pH}$ range.

The impact of carbon source on enzyme production was checked by using different carbon sources in the production medium. The data show that the polysaccharides such as starch and CMC support the production of cellulase enzyme (Fig. 3). The results were comparable to Sadhu et al. [24]. The Bacillus strain under the investigation was found to produce maximum cellulase enzyme in the presence of CMC as a carbon source. The highest enzyme activity was shown by $\mathrm{S} 1-1$, i.e., $5.871 \mathrm{U} / \mathrm{ml}$, in presence of starch as a sole source of carbon. The enzyme activities were found to be almost comparable in the presence of sucrose and maltose as a sole source of carbon. The enzyme activity was found to be negligible when glucose was used as a carbon source in the production medium. The above-mentioned data suggest that glucose does not support the cellulase production for the above-mentioned isolates. In contrast to this, Sethi et al. [15] found that the glucose was the best carbon source to produce cellulase enzyme by the bacterial isolates. The above-mentioned data suggest that $\mathrm{CMC}$ and starch were the most suitable carbon sources for cellulase production. However, disaccharides such as sucrose and maltose can also support the enzyme production. Shajahan et al. [34] reported that $\mathrm{CMC}$ is a crucial factor to produce cellulase enzyme. The data suggest that polysaccharides such as CMC and starch are needed for the production of cellulase enzyme. 

cellulase production 2021;9(06):154-161

Table 2. Cellulase activity of isolates at different $\mathrm{pH}$.

$\begin{array}{ccccccc}\text { Strain number } & \mathbf{p H ~ 2} & \mathbf{p H ~ 4} & \mathbf{p H ~ 6} & \mathbf{p H ~ 7} & \mathbf{p H ~ 8} & \mathbf{p H ~ 1 0} \\ \mathrm{S} 1-1 & 0.403 \pm 0.13 & 1.302 \pm 0.09 & 3.082 \pm 0.58 & 0.109 \pm 0.02 & 0.599 \pm 0.06 & 0.116 \pm 0.01 \\ \mathrm{~S} 1-4 & 0.649 \pm 0.06 & 1.902 \pm 0.24 & 1.967 \pm 0.26 & 2.184 \pm 0.16 & 0.084 \pm 0.02 & 0.304 \pm 0.11 \\ \mathrm{~S} 3-3 & 0.28 \pm 0.14 & 1.603 \pm 0.72 & 1.286 \pm 0.06 & 1.214 \pm 0.09 & 2.115 \pm 0.14 & 0.521 \pm 0.04 \\ \mathrm{~S} 4-1 & 0.928 \pm 0.05 & 1.569 \pm 0.07 & 0.974 \pm 0.06 & 0.613 \pm 0.08 & 0.179 \pm 0.01 & 0.127 \pm 0.02 \\ \mathrm{~S} 4-2 & 0.509 \pm 0.07 & 1.237 \pm 0.24 & 0.927 \pm 0.12 & 0.435 \pm 0.03 & 1.171 \pm 0.12 & 0.19 \pm 0.05 \\ \mathrm{~S} 7-2 & 0.476 \pm 0.08 & 0.819 \pm 0.17 & 2.672 \pm 0.33 & 1.343 \pm 0.43 & 0.315 \pm 0.05 & 0.196 \pm 0.03 \\ \mathrm{~S} 7-6 & 0.89 \pm 0.13 & 0.68 \pm 0.1 & 1.428 \pm 0.24 & 1.105 \pm 0.07 & 0.677 \pm 0.06 & 1.463 \pm 0.2 \\ & & \mathrm{CD} & p \text {-value } & & & \\ & \mathrm{Strain} & 0.682111 & 0.000159 & & & \\ & \mathrm{pH} & 0.631512 & 2.47 \mathrm{E}-22 & & & \\ & \text { Strain } \times \mathrm{pH} & 0.556941 & 2.25 \mathrm{E}-17 & & & \\ \end{array}$

Table 3. Cellulase activity of isolates at different temperature.

$\begin{array}{cccccc}\text { Strain number } & \mathbf{4}^{\circ} \mathrm{C} & \mathbf{1 0 ^ { \circ } \mathrm { C }} & \mathbf{2 7 ^ { \circ } \mathrm { C }} & \mathbf{3 7}^{\circ} \mathrm{C} & \mathbf{5 0}^{\circ} \mathrm{C} \\ \mathrm{S} 1-1 & 0.973 \pm 0.06 & 1.622 \pm 0.51 & 3.913 \pm 0.18 & 3.553 \pm 0.36 & 1.141 \pm 0.28 \\ \mathrm{~S} 1-4 & 1.727 \pm 0.34 & 1.221 \pm 0.15 & 1.923 \pm 0.56 & 1.602 \pm 0.15 & 1.255 \pm 0.24 \\ \mathrm{~S} 3-3 & 1.364 \pm 0.11 & 3.425 \pm 0.5 & 3.165 \pm 0.64 & 2.359 \pm 0.48 & 0.779 \pm 0.21 \\ \mathrm{~S} 4-1 & 0.983 \pm 0.09 & 4.316 \pm 0.58 & 4.909 \pm 0.95 & 2.3 \pm 0.06 & 6.226 \pm 0.73 \\ \mathrm{~S} 4-2 & 0.245 \pm 0.06 & 3.376 \pm 0.3 & 3.92 \pm 0.37 & 2.759 \pm 0.13 & 2.117 \pm 0.37 \\ \mathrm{~S} 7-2 & 0.397 \pm 0.11 & 3.622 \pm 0.83 & 4.282 \pm 0.48 & 4.437 \pm 0.23 & 0.587 \pm 0.2 \\ \mathrm{~S} 7-6 & 0.331 \pm 0.07 & 3.219 \pm 0.32 & 4.544 \pm 0.07 & 1.96 \pm 0.28 & 3.466 \pm 0.55 \\ & & \mathrm{CD} & p \text {-value } & & \\ & \text { Strain } & 1.169461 & 1.87 \mathrm{E}-10 & & \\ & \text { temperature } & 0.83533 & 2.4 \mathrm{E}-20 & & \\ & \text { Strain } \times \text { temperature } & 0.649701 & 1.08 \mathrm{E}-12 & & \\ \end{array}$

Table 4. Cellulase activity of isolates with different carbon sources.

\begin{tabular}{|c|c|c|c|c|c|}
\hline Strain number & CMC & Starch & Sucrose & Glucose & Maltose \\
\hline S1-1 & $2.593 \pm 0.3$ & $5.871 \pm 0.63$ & $1.098 \pm 0.03$ & $3.106 \pm 0.6$ & $2.033 \pm 0.17$ \\
\hline S1-4 & $0.939 \pm 0.28$ & $1.356 \pm 0.05$ & $1.814 \pm 0.83$ & $0.616 \pm 0.09$ & $2.407 \pm 0.61$ \\
\hline S3-3 & $4.695 \pm 0.79$ & $1.093 \pm 0.11$ & $1.368 \pm 0.14$ & $0.135 \pm 0.03$ & $2.153 \pm 0.09$ \\
\hline S4-1 & $3.295 \pm 0.76$ & $1.725 \pm 0.35$ & $1.542 \pm 0.43$ & $0.055 \pm 0.02$ & $5.272 \pm 0.75$ \\
\hline S4-2 & $1.125 \pm 0.06$ & $2.589 \pm 0.29$ & $3.94 \pm 0.68$ & $1.201 \pm 0.28$ & $3.315 \pm 0.71$ \\
\hline S7-2 & $1.238 \pm 0.26$ & $1.06 \pm 0.14$ & $3.043 \pm 0.46$ & $0.749 \pm 0.23$ & $3.287 \pm 0.54$ \\
\hline \multirow[t]{5}{*}{ S7-6 } & $1.843 \pm 0.45$ & $2.614 \pm 0.76$ & $1.46 \pm 0.16$ & $0.106 \pm 0.06$ & $4.158 \pm 0.94$ \\
\hline & & & $\mathrm{CD}$ & $p$-value & \\
\hline & & Strain & 1.756032 & $8.78 \mathrm{E}-05$ & \\
\hline & & Carbon sources & 1.484118 & $1.94 \mathrm{E}-12$ & \\
\hline & & Strain $\times$ carbon sources & 0.755676 & $1.36 \mathrm{E}-12$ & \\
\hline
\end{tabular}

Recent reports on the isolation of cellulolytic bacteria suggest that Bacillus is one of the potential genera of bacteria which produces cellulase enzyme $[8,23,24,29,34,35]$. The cellulases produced by different microbial sources could be further explored for their potential to degrade different lignocellulosic waste materials [4,12,23]. Sibiya et al. [36] tested the efficacy of cellulase enzyme for degradation of waste newspapers. The Bacillus strains identified under the present study could be further explored for their ability to produce cellulase enzyme for degradation of several natural substrates that are rich in lignocellulose.

\subsection{Statistical Analysis}

The results of optimization were analyzed using a two-factor ANOVA test with significance level of $p<0.05$ using Microsoft excel 2013 and the results are tabulated for enzyme activities of 
the isolates for different parameters (Tables 2-4). The data reveal that the enzyme activities shown by different isolates were found to be significantly different. Although all the isolates belonged to Bacillus species, their cellulolytic potential was unique with respect to each strain. Also, there was a significant difference in the enzyme activities of the isolates at different $\mathrm{pH}$, temperatures, and carbon sources.

\section{CONCLUSION}

The main aim of the present work was to screen and isolate the best cellulase-producing bacteria from soil sample. Seven best cellulase-producing isolates were found during the work. All the isolates were found to be Gram-positive in nature and were identified to be Bacillus species using 16S rRNA gene-based sequencing. Bacillus is the most abundant bacterium present in soil with a great cellulolytic potential. The results of optimization indicate that the most optimum temperature range for cellulase production by the above-mentioned isolates was $27^{\circ} \mathrm{C}-37^{\circ} \mathrm{C}$. It may be concluded that Bacillus strains isolated in the present study can produce cellulase enzyme at a $\mathrm{pH}$ range of $6-8$. The data suggest that the enzymes produced form these isolates could be used for the hydrolysis of mild acid or alkali treated substrates. The presence of polysaccarides and disaccharides in the medium may have an inductive effect on cellulase production. The future study aims at partial purification and characterization of the cellulase enzymes produced above-mentioned isolates. The purified enzyme could be used further for hydrolysis and saccharification of lignocellulosic biomass such as rice straw, rice husk, sugarcane bagasse, and other lignocellulosic substrates, which is a major step during bioethanol production.

\section{ACKNOWLEDGMENTS}

The authors are thankful to the Principal, Changu Kana Thakur College of Arts, Commerce and Science, New Panvel, for continuous support for the successful completion of the research work. The authors gratefully acknowledge the University of Mumbai, India, for encouragement given to design and conduct the research work.

\section{AUTHORS' CONTRIBUTION}

Both the authors contributed equally to the design of the research experiments. Both have been actively involved in the finalization and revision of the manuscript. Analysis and interpretation of the data are also carried out by both the authors.

\section{FUNDING}

There is no funding to report.

\section{CONFLICTS OF INTEREST}

The authors report no financial or any other conflicts of interest in this work.

\section{ETHICAL APPROVALS}

This study does not involve experiments on animals or human subjects.

\section{REFERENCES}

1. Prasad M, Sethi R, Anand M, Padmavathi T. Degradation of agrowastes by lignocellulolytic activity of bacterial isolates from marine sources. Asian J Plant Sci Res 2014;4(2):60-3.

2. Brodeur G, Yau E, Badal K, Collier J, Ramachandran KB, Ramakrishnan S. Chemical and physicochemical pretreatment of lignocellulosic biomass: a review. Enzyme Res 2011;2011:1-17; doi:10.4061/2011/787532

3. Tandon D, Sharma N. Isolation of potential novel cellulolytic and xylanolytic bacteria and optimization of their cultural conditions for enhanced production of cellulase and xylanase. J Agroaliment Proc Technol 2014;20:231-40.

4. Premalatha N, Gopal NO, Jose PA, Anandham R, Kwon SW. Optimization of cellulase production by Enhydrobacter sp. ACCA2 and its application in biomass saccharification. Front Microbiol 2015;6:1046; doi:10.3389/fmicb.2015.01046

5. Hassan SS, Williams GA, Jaiswal AK. Emerging technologies for the pretreatment of lignocellulosic biomass. Bioresour Technol 2018;262:310-8; doi:10.1016/j.biortech.2018.04.099

6. Bai H, Wang H, Junde Sun MI, Han M, Huang Y, Han X, et al. Production, purification and characterization of novel beta glucosidase from newly isolated Penicillium simplicissimum $\mathrm{H}-11$ in submerged fermentation. EXCLI J 2013;12:528.

7. Pothiraj C, Kanmani P, Balaji P. Bioconversion of lignocellulose materials. Mycobiology 2006;34(4):159-65; doi:10.4489/MYCO. 2006.34.4.159

8. Shanmugapriya K, Saravana PS, Krishnapriya MM, Mythili A, Joseph $\mathrm{S}$. Isolation, screening and partial purification of cellulase from cellulase producing bacteria. Int J Adv Biotechnol Res 2012;3:50914.

9. Liang YL, Zhang Z, Wu M, Wu Y, Feng JX. Isolation, screening, and identification of cellulolytic bacteria from natural reserves in the subtropical region of China and optimization of cellulase production by Paenibacillus terrae ME27-1. BioMed Res Int 2014;2014:1-13; doi:10.1155/2014/512497

10. Vatanparast M, Hosseininaveh V, Ghadamyari M, Sajjadian SM. Plant cell wall degrading enzymes, pectinase and cellulase, in the digestive system of the red palm weevil, Rhynchophorus ferrugineus (Coleoptera: Curculionidae). Plant Prot Sci 2014;50(4):190-8; doi:10.17221/43/2013-PPS

11. Srivastava N, Srivastava M, Manikanta A, Ramteke PW, Singh RL, Mishra PK, Upadhyay SN. Fungal cellulases production for biodegradation of agriculture waste. In: Panpatte DG, Shelat HN, Vyas RV, Jhala YK (eds.). Microorganisms for green revolution. Springer, Singapore, pp 75-89, 2018; doi:10.1007/978-981-10-7146-1_4

12. Burugu A, Suman DK, Chanda C. Production and purification of extracellular fungal cellulases using agricultural waste. J Appl Biol Biotechnol 2021;9(2):153-6; doi:10.7324/JABB.2021.9214

13. Maki M, Leung KT, Qin W. The prospects of cellulase-producing bacteria for the bioconversion of lignocellulosic biomass. Int J Biol Sci 2009;5(5):500; doi:10.7150/ijbs.5.500

14. Jayasekara S, Ratnayake R. Microbial cellulases: an overview and applications. Cellulose 2019;22; doi:10.5772/intechopen.84531

15. Sethi S, Datta A, Gupta BL, Gupta S. Optimization of cellulase production from bacteria isolated from soil. Int Sch Res Notices 2013;2013:1-7; doi:10.5402/2013/985685

16. Saini A, Aggarwal NK, Yadav A. Isolation and screening of cellulose hydrolyzing bacteria from different ecological niches. J Biosci Bioeng 2017;5:7-13; doi:10.13189/bb.2017.050102

17. Maravi P, Kumar A. Isolation, screening and identification of cellulolytic bacteria from soil. Biotechnol J Int 2020;2020:1-8; doi:10.9734/BJ//2020/v24i130092

18. Kasana RC, Salwan R, Dhar H, Dutt S, Gulati A. A rapid and easy method for the detection of microbial cellulases on agar plates using 
Gram's iodine. Curr Microbiol 2008;57(5):503-7; doi:10.1007/ s00284-008-9276-8

19. Wilson K. Preparation of genomic DNA from bacteria. Curr Protoc Mol Biol 2001;56(1):2-4; doi:10.1002/0471142727.mb0204s56

20. Weisburg WG, Barns SM, Pelletier DA, Lane DJ. 16S ribosomal DNA amplification for phylogenetic study. J Bacteriol 1991;173(2):697.

21. Altschul SF, Gish W, Miller W, Myers EW, Lipman DJ. Basic local alignment search tool. J Mol Biol 1990;215(3):403-10.

22. Miller GL. Use of dinitrosalicylic acid reagent for determination of reducing sugar. Anal Chem 1959;31(3):426-8.

23. Dabhi BK, Vyas RV, Shelat HN. Use of banana waste for the production of cellulolytic enzymes under solid substrate fermentation using bacterial consortium. Int J Curr Microbiol Appl Sci 2014;3(1):337-46.

24. Sadhu S, Saha P, Sen SK, Mayilraj S, Maiti TK. Production, purification and characterization of a novel thermotolerant endoglucanase (CMCase) from Bacillus strain isolated from cow dung. Springerplus 2013;2(1):1-10; doi:10.1186/2193-1801-2-10

25. Saha B, Roy S, Hossen F. Isolation and identification of cellulolytic bacteria from soil sample and their antibiogram. Am J Microbiol Res 2019;7(3):83-90; doi:10.12691/ajmr-7-3-3

26. Lednická D, Mergaert J, Cnockaert MC, Swings J. Isolation and identification of cellulolytic bacteria involved in the degradation of natural cellulosic fibres. Syst Appl Microbiol 2000;23(2):292-9; doi:10.1016/S0723-2020(00)80017-X

27. Sharma N, Sharma N. Cost effective production of cellulase and xylanase enzymes by Myceliophthora thermophila SH1 using lignocellulosic forest waste and bioconversion of alkaline hydrogen peroxide pretreated $P$. deltoides wood to bioethanol under SHF. J Agroaliment Processes Technol 2013;19(4):419-28.

28. Ja'afaru MI. Screening of fungi isolated from environmental samples for xylanase and cellulase production. Int Scholarly Res Notices 2013;2013 1-7; doi:10.1155/2013/283423

29. Islam M, Sarkar PK, Mohiuddin AK, Suzauddula M. Optimization of fermentation condition for cellulase enzyme production from Bacillus sp. Malays J Halal Res 2019;2(2):19-24; doi:10.2478/mjhr-20190009

30. Rasul F, Afroz A, Rashid U, Mehmood S, Sughra K, Zeeshan N. Screening and characterization of cellulase producing bacteria from soil and waste (molasses) of sugar industry. Int J Biosci 2015;6(3):230 6; doi:10.12692/ijb/6.3.230-238

31. Gautam SP, Bundela PS, Pandey AK, Khan J, Awasthi MK, Sarsaiya S. Optimization for the production of cellulase enzyme from municipal solid waste residue by two novel cellulolytic fungi. Biotechnol Res Int 2011;2011 1-8; doi:10.4061/2011/810425

32. Maryam B, Qadir A, Zameer M, Ahmad SR, Nelofer R, Jamil N, et al. Production of cellulases by Bacillus cellulosilyticus using lignocellulosic material. Pol J Environ Studies 2018;27(6):1-9; doi:10.15244/PJOES/80867

33. Nandimath AP, Kharat KR, Gupta SG, Kharat AS. Optimization of cellulase production for Bacillus sp. and Pseudomonas sp. soil isolates. Afr J Microbiol Res 2016;10(13):410-9; doi:10.5897/ AJMR2016.7954

34. Shajahan S, Moorthy IG, Sivakumar N, Selvakumar G. Statistical modeling and optimization of cellulase production by Bacillus licheniformis NCIM 5556 isolated from the hot spring, Maharashtra, India. J King Saud Univ Sci 2017;29(3):302-10; doi:10.1016/j. jksus.2016.08.001

35. Khianngam S, Pootaeng-on Y, Techakriengkrai T, Tanasupawat S. Screening and identification of cellulase producing bacteria isolated from oil palm meal. J Appl Pharm Sci 2014;4(4):90; doi:10.7324/ JAPS.2014.40416

36. Sibiya JB, Wyk JP. Bioconversion of waste newspaper into fermentable sugars at different temperatures with different Aspergillus niger cellulase concentrations. J Appl Biol Biotechnol 2016;4(04):69-74; doi:10.7324/JABB.2016.40408

\section{How to cite this article:}

Bhagat SA, Kokitkar SS. Isolation and identification of bacteria with cellulose-degrading potential from soil and optimization of cellulase production. J Appl Biol Biotech 2021; 9(06):154-161. 